\title{
Intentions on desired length of stay among immigrants in Italy
}

Elisa Barbiano di Belgiojoso

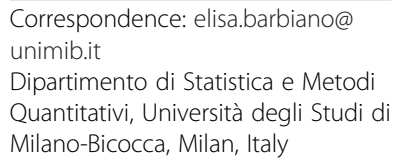

Correspondence: elisa.barbiano@ unimib.it

Dipartimento di Statistica e Metodi Quantitativi, Università degli Studi di Milano-Bicocca, Milan, Italy

\begin{abstract}
The decision to emigrate from the country of origin may not be a permanent one: migrants can decide to return home or to emigrate to a third country. This phenomenon, established for some time in certain other European countries, has become an important one for Italy only recently.

This paper contributes to the knowledge of migrants' intentions in two ways: on the one hand, it analyses the factors associated with indecision about future plans; on the other, it focuses on the desired length of stay and its relationship with attachments (family, economic, socio-cultural and psychological) to host and home country.

We used two logistic regression models: one for migrants' indecision and the other for migrants' desired length of stay. The data were collected by survey, coordinated by the ISMU Foundation and conducted in 2008 and 2009 with more than 12,000 migrants living in Italy.

According to our results, indecision seems to be associated with an intermediate phase of migration at the early stage of family development in the case of negative balance of the migration experience, while attachment to the host country is associated with longer stay, and no attachments or attachment to the country of origin are associated with shorter stay.
\end{abstract}

Keywords: Migration intention, Remigration, Settlement, Length of stay, Italy

\section{Background}

The strength of migration pressure experienced by the major receiving countries in the last few years of a major economic crisis caused by an increase in unemployment has rekindled an academic debate about the emigration of immigrants, hereafter referred to as remigration.

While for a long time the decision to emigrate from the country of origin was generally regarded as permanent, numerous studies have shown that such decisions were, and still are, reversible ones (see, for example, Da Vanzo 1976, 1983; King 1978; Borjas and Bratsberg 1996; Dustmann 2003a; Dustmann and Weiss 2007; Carling and Erdal 2014). Recently, complex migration trajectories have been identified indicating that remigration itself is also reversible (Carling and Erdal 2014).

A migrant has three options: stay in the host country, return to his/her country of birth (return migration) or move on to a third country (secondary or onward migration). ${ }^{1}$ Depending on the available information, the literature has frequently compared and contrasted, two-by-two, these options and the characteristics of migrants who are returnees

(C) 2016 The Author(s). Open Access This article is distributed under the terms of the Creative Commons Attribution 4.0 International License (http://creativecommons.org/licenses/by/4.0/), which permits unrestricted use, distribution, and reproduction in any medium provided you give appropriate credit to the original author(s) and the source, provide a link to the Creative Commons license, and indicate if changes were made. 
or stayers (e.g. Constant and Massey 2002; Jensen and Pedersen 2007; Borodak and Tichit 2013; de Vroome and van Tubergen 2014) and returnees or onward migrants (da Vanzo 1976, 1983; Newbold and Bell 2001; Nekby 2006). Less frequently, a comparison of the three options was made (e.g. Schroll 2009; Barbiano di Belgiojoso and Ortensi 2013).

Moreover, the two possible options of remigration were differently debated: while the literature has deeply analysed characteristics of return migration and returnees (see for example Cassarino 2004 or de Haas and Fokkema 2011 for a literature review), onward migration has been less studied (see, for example, Da Vanzo 1976, 1983; Nekby 2006; Toma and Castagnone 2015). In both cases, the immigrant leaves the host country, but the determinants of the migrant's decision are generally different, as are his/ her plans for the future and his/her behaviour in the host country such as efforts to integrate, make plans for family futures, etc. (Da Vanzo 1976, 1983 and reference therein; Newbold and Bell 2001; Nekby 2006; OECD 2008; Barbiano di Belgiojoso and Ortensi 2013; Carling and Pettersen 2014). Despite this, few quantitative studies were able to distinguish these two types of remigrations (Nekby 2006; Schroll 2009; Toma and Castagnone 2015).

For those migrants who do not intend to settle or do not settle in the host country, another analysed issue is the length of stay and its determinants (Dustmann 2001; Constant and Massey 2003; Carrión-Flores 2006; Mara and Landesmann 2013).

Thus, there are two different levels of analysis: (1) to consider the actually realised behaviour and the length of stay, an approach less frequently applied due to the data required (e.g. Da Vanzo 1983; Borjas and Bratsberg 1996; Reagan and Olsen 2000; Dustmann 2003a; Nekby 2006; Jensen and Pedersen 2007; Toma and Castagnone 2015), or (2) to consider migration intentions and eventually the desired length of stay, the approach more frequently used (e.g. Waldorf 1995; Ahlburg and Brown 1998; Coniglio et al. 2009; Zaiceva and Zimmermann 2008 and references therein; de Haas and Fokkema 2011; Anniste and Tammaru 2014; de Vroome and van Tubergen 2014; Carling and Pettersen 2014; Carling and Erdal 2014) despite the widespread scepticism. ${ }^{2}$ Only in a few cases has there been the opportunity to analyse the relationship between intentions and actual behaviour (Dustmann 2003a; Van Baalen and Müller 2008; Diehl and Liebau 2015).

Migration became an issue for Italy more recently than for most other countries, but after two decades of rising numbers of migrants, Italy is one of the main receiving countries (Strozza 2010) with 5 million of resident foreigners at the beginning of 2015. However, according to the available data, the percentage of migrants intending to leave Italy has considerably increased (Terzera 2015) indicating a change both in migration flows and in the importance for Italy of the role of remigration (Blangiardo 2012).

With the exception of the studies by Coniglio et al. (2009), Barbiano di Belgiojoso and Ortensi (2013) and Ortensi and Barbiano di Belgiojoso (2015), to the best of our knowledge, little research has been recently conducted specifically on the migrants' intentions in Italy, due to the lack of data $^{3}$ on this phenomenon which is relatively new for Italy.

This paper contributes to the knowledge of migrants' intentions in two ways: on the one hand, it analyses the factors associated with indecision about future plans; on the other, it focuses on the desired length of stay and its relationship with attachments to host and home country. 
The study analyses future intentions of migrants coming from the high emigration countries who were living in Italy in 2008-2009.

The remainder of the paper is structured as follows. The 'What may influence migrants' intentions and behaviour? The literature review' section presents a review of the international literature on migrants' intentions and behaviour, and the 'Research hypotheses' section outlines the research hypotheses. Then, after a description and a discussion of the data and methods in the 'Data, measurement and methods' section, the 'Results' section outlines and discusses the empirical results. The 'Conclusions' section concludes.

\section{What may influence migrants' intentions and behaviour? The literature review}

There is still no consensus on the determinants of migrants' intentions and predictors of migrants' behaviour. The existence of multiple paths of migrations, multiple destinations and origins leads to the lack of consensus on the determinants or predictors of the migration or remigration intention. Frequently, studies reach opposite conclusions, especially with regard to the economic dimension (Constant and Massey 2002; de Haas and Fokkema 2011), to the integration process (de Haas and Fokkema 2011; Anniste and Tammaru 2014) and to transnationalism practices (Carling and Pettersen 2014). Bearing this in mind, we have tried to summarise the main results from the literature, even if they sometimes contrast or overlap.

Usually the focus of the previous analyses has been remigrations and re-emigrants rather than settlement and stayers' characteristics. Therefore, in order to deduce factors associated with settlement and different lengths of stay, we first consider the reasons for remigrations and the characteristics of re-emigrants, both return and onward separately.

\section{Return migration}

Return migration has been deeply analysed especially as an alternative to permanent settlement, based on the returnees' typologies identified between the 1970s and 1980s (Cerase 1974; King 1978; Gmelch 1980 and references therein). Recently, return migration was considered also as an alternative compared to onward migration.

Frequently, the debate about return migration or return intention has been reduced to the mere consequence of the success or failure of the original migration project-both in terms of economics and integration-isolating the decision from the context and concentrating on the consequent selection effect produced by return migration. Are the 'best' or the 'worst' those who leave? Are they the 'most integrated' or the 'least integrated' (Constant and Massey 2002; Cassarino 2004; Rooth and Saarela 2007; Dell'Aringa and Pagani 2011; de Haas and Fokkema 2011; Carling and Pettersen 2014)? Hence, for example, the neoclassical theory considers return as a failure of the migration plan or as a mistake in the initial migration decision aimed at settlement (Massey et al. 1993; Constant and Massey 2002). Hence, those who obtain a good job, higher income and higher integration (the 'best') remain, while those who do not succeed (the 'worst') leave (see, for example, Jensen and Pedersen 2007). Conversely, according to the New Economics of Labour Migration (NELM) approach, return migration is a logical 
outcome of the migration plan once migrants have fulfilled their goals and have accumulated enough financial and human capital to reinvest in the country of origin (Stark and Bloom 1985; Stark 1991; Borjas and Bratsberg 1996; Taylor 1999). Hence, the 'worst' are those who remain, being the ones who need more time to achieve their savings target, and the 'best' are those who leave the host country. As widely demonstrated, empirical evidence supports both the approaches (Constant and Massey 2002; Dustmann and Weiss 2007; Jensen and Pedersen 2007; de Haas and Fokkema 2011; Dell'Aringa and Pagani 2011; Carling and Pettersen 2014).

The structural approach considers the context: migrants' decisions are driven by the comparison between the opportunities they anticipate having in their countries of origin and what they expect in the host country (Gmelch 1980; Black et al. 2004; Cassarino 2004). Therefore, the returnees are migrants who decide they have better opportunities (Black et al., 2004) or location-specific preferences (e.g. Hill 1987) in their country of origin.

Moreover, according to the transnationalism theory, return migration is part of a circular system and is prepared for by migrants through periodic visits to their country of origin and by remittances. These back-and-forth movements of migrants, made possible by the globalisation of communication technologies, maintain the links between origin and host countries and generate dual loyalties, identities and attachments (Portes et al. 1999; Carling and Pettersen 2014). Hence, from this perspective, ties with the country of origin are no longer thought of as a barrier to the process of integration (Cela et al. 2013; Carling and Pettersen 2014). Consequently, the relationship between integration/attachment to the country of residence, transnational practices/attachment to the country of origin and return migration or migration intention is neither linear nor predictable (e.g. de Haas and Fokkema 2011; Carling and Pettersen 2014).

Finally, migrants' decisions or intentions are often correlated with family or other non-economic considerations since they cannot be interpreted simply as a direct response to changes in the opportunities offered by the labour market (Gmelch 1980; King 2000; Nauck and Settle 2001; Kofman 2004; Kraler et al. 2011; Evergeti and Ryan 2011; Vlase 2013; Erdal and Ezzati 2014). In fact, 'the decision to migrate is thus typically not justified by the expected outcomes for the individual migrant alone, but by the outcomes for other family members as well' (Nauck and Settle 2001, p. 462). Moreover, the timings of migration or possible return are closely related to family life cycle, thus must be thought of as embedded in the life cycle of the family (Nauck and Settle 2001; King 2002; Dustmann 2003b; King et al. 2004; Erdal and Ezzati 2014). Hence, migrants who return home include those who want their children to grow up in the country of origin, who need to attend elderly parents at home (Gmelch 1980; Erdal and Ezzati 2014) and who want to retire in their country of origin (OECD 2008; Erdal and Ezzati 2014) and to be buried in the country of origin (Mazzucato et al. 2006).

\section{Onward migration}

As stated in the "Background" section, onward migration within Europe has been less studied (Nekby 2006; Benton and Petrovic 2013), although it is an increasingly common mobility practice due to the reversibility of migration flows and to the economic crisis (Nekby 2006; Takenaka 2007; Toma and Castagnone 2015). The lack of studies 
could be partly ascribable to the lack of data recording the entire trajectory of migrants (Toma and Castagnone 2015); moreover, the study of onward migration changes the dichotomy 'home' and 'host' (Jefrey and Murison 2011) when introducing movements towards several destinations.

Scholars have conceptualised onward migrations in different ways (Toma and Castagnone 2015). One group of scholars (Takenaka 2007; Paul 2011) has adopted the concept of 'stepwise migration' grounded on the idea that migrants plan in advance to make several steps before attaining their final destination; stepwise migration may be essential in order to accumulate the capital needed to attain their destination or to bypass certain legal barriers to entry in favour of entry where there are lower controls; later, they will move to their real destination. A second group of scholars (e.g. Da Vanzo 1983; Newbold and Bell 2001; Schapendonk 2012; Kelly 2013; Toma and Castagnone 2015) has adopted the concept of 'continuing mobility' to indicate that migrants do not have a preferred destination or do not plan in advance a second migration, but emigrate a second time (or intend to emigrate again) due to a continued revaluation of the opportunities elsewhere; they look for social mobility, legal integration, career advancement and 'better life' through a trial-and-error mechanism or according to the knowledge acquired during the migration experience.

What drives onward mobility? And who are onward migrants? Although motivation for onward migration can overlap, based on typologies proposed by Ahrens et al. (2014), we can classify onward migrants into four categories. First, migrants emigrate for career reasons, looking either for a job (lost sometimes due to the economic crisis) or better labour opportunities as they cannot find jobs commensurate to their skills or potential for upward mobility (Da Vanzo 1983; Hou and Beaujot 1994; Newbold and Bell 2001; Nekby 2006; Schroll 2009; Paul 2011; Barbiano di Belgiojoso and Ortensi 2013; Ahrens et al. 2014; Erdal and Ezzati 2014; Toma and Castagnone 2015) with a consequent positive or negative selection based on education and income. Second, migrants move to a third country for family reasons, looking for better life conditions for their children especially for study and professional opportunities (Castagnone 2011; Ahrens et al. 2014; Erdal and Ezzati 2014). Third, migrants move to a third country, dissatisfied with the changing integration policies in the current host country and looking for better integration opportunities in the third country (Ahrens et al. 2014; Haandrikman and Hassanen 2014). And finally, migrants emigrate to a third country to follow their personal and other networks: for example, migrants reallocate within Europe to be closer to family and friends in another European country (Schroll 2009; Schapendonk 2012; Ahrens et al. 2014; Erdal and Ezzati 2014; Toma and Castagnone 2015).

\section{Deciding to stay}

A further decision option for migrants is to decide to stay. The decision or intention to stay seems to be more likely when the attachments to the host country (Reagan and Olsen 2000; Constant and Massey 2002; Waldinger 2008), also defined as 'location-specific capital' (Da Vanzo 1983), prevail over and beyond their home country attachments (e.g. Da Vanzo 1983; Erdal and Ezzati 2014; de Vroome and van Tubergen 2014; Anniste and Tammaru 2014). Hence, the more location-specific capital a migrant has 
in the host country, the more likely he or she will stay (Da Vanzo 1983; Hill 1987; Erdal and Ezzati 2014).

According to the literature, the attachments to the host country assume different forms: political (legal and residential status), economic (home ownership, professional stability), family (the presence of other family members in emigration in the host country), sociocultural (to have friendships with natives as well as emigrants and easier integration) and psychological (sense of belonging to the host country). Specifically, homeownership is commonly considered as strongly connected to the decision or intention to stay (Da Vanzo 1983; Constant and Massey 2002, 2003; Bastia 2011; Delpierre and Verheyden 2014). Similarly, each form of savings in the host country is associated with permanent settlement or longer stay (Delpierre and Verheyden 2014). Contacts with natives and agreement with cultural values in the host country both increase the settlement probability (de Vroome and van Tubergen 2014) while family attachment (children and partner), integration, sense of belonging to the host country and legal status seem to have an ambiguous effect on the intention to stay (Constant and Massey 2002; Schroll 2009; de Haas and Fokkema 2011; Borodak and Tichit 2013; Carling and Pettersen 2014; Erdal and Ezzati 2014). Symmetrically, attachments to the country of origin that have been considered are family ties; nostalgia for the culture, the climate and the life style of the country of origin; and feeling of loyalty or allegiance to the home society and remittances (e.g. Gmelch 1980; Hill 1987; de Haas and Fokkema 2011; Erdal and Ezzati 2014).

However, it should be noticed that these attachments, especially the socio-cultural ones, are not a 'zero-sum game' (Carling and Pettersen 2014); therefore, a strong attachment to the country of origin does not prevent a strong attachment to the host country. The range of factors thus should be combined in order to capture their association to migrants' intentions. Indeed, migrants weakly integrated and strongly transnational have the lowest likelihood of settlement, strongly integrated and weakly transnational the highest, while the other categories show similar likelihood of settlement.

Finally, the decision and the intention to stay are strongly connected to the life cycle stage and are related to the number of persons depending on the migrant (number of family members), especially children (Nauck and Settle 2001; Dustmann 2003b; Erdal and Ezzati 2014).

\section{Length of stay}

In addition to the direction of the possible outmigration flow, another important dimension is the length of stay. According to Mara and Landesmann (2013), little is known about the expected length of stay in the host country. Frequently, only migrants' plans or behaviours are analysed without focusing specifically on the length of stay (desired or actual).

However, some results emerge from the literature: the length of stay is generally considered positively related to, first, the costs-monetary and non-monetary-of the migration (Hill 1987; Carrión-Flores 2006; Borodak and Tichit 2013). A second aspect is the family context in the host country such as the presence of the family in emigration, homeownership and the educational stage of children (Steiner and Velling 1994; Carrión-Flores 2006; Mara and Landesmann 2013). Third, must be considered the 
satisfaction with the job and the migration experience (Mara and Landesmann 2013). On the other side, length of stay is generally negatively related to family ties (Hill 1987; Borodak and Tichit 2013), an early stage of family formation (Carrión-Flores 2006), remittances (Dustmann and Mestres 2010; Mara and Landesmann 2013) and educational level of migrants-the more educated usually leave the host country before the less educated (Mara and Landesmann 2013).

Finally, contrasting results were found for the wage differential between sending and receiving regions (Dustmann 2003a; Yang 2006; Borodak and Tichit 2013) and networks (Schroll 2009; Mara and Landesmann 2013). As stated above, empirical evidence supports contrasting results also for integration and labour market participation (Constant and Massey 2003; Jensen and Pedersen 2007; Constant and Zimmermann 2011; de Haas and Fokkema 2011; Mara and Landesmann 2013; Carling and Pettersen 2014). More specifically, those who stay longer or intend to stay longer may be either those who have found a good job and have integrated in the host society or those who need more time to achieve their savings goals.

\section{Research hypotheses}

Considering the arguments presented in the previous section, we formulate our research hypotheses.

To the best of our knowledge, very few studies focused on indecision. Considering these previous results (de Haas and Fokkema 2011; Erdal and Ezzati 2014), we can postulate that, after the first settling-in period, migrants question their initial plan, evaluating their experience regarding economic, family and socio-cultural aspects. Indecision is higher in cases of economic difficulties, when migrants still have a transnational family or when they are not completely satisfied with their migration experience. While indecision is lower after a long time in emigration and once migrants have acquired more experience and information about the host country, they may still decide to leave the host country.

\section{Hypothesis 1: Indecision is positively associated with an intermediate step of} migration, economic difficulties, transnational family and dissatisfaction with the migration experience.

In accordance with previous results (Da Vanzo 1983; Hill 1987; Erdal and Ezzati 2014), we assume that migrants' intentions are associated with the comparison of attachments in their different forms-economic, political, family, psychological and socio-cultural-to country of origin and host country. Thus, the stronger attachment a migrant has in the host country, the more likely he/she intends to stay for a longer time. Conversely, the stronger attachments a migrant has in the country of origin, the more likely he/she intends to stay for a shorter time. In particular, migrants will have a higher probability of settlement in the host country if they have begun the process of obtaining legal and residential status, or they have invested money in a home, or they have a predominant sense of belonging to the host country, or they speak more frequently the host country language and agree with the host country lifestyle. This leads to the following hypothesis: 
Hypothesis 2a: Migrants with strong attachments to Italy have a longer desired length of stay;

Hypothesis 2b: Migrants with strong attachments to the country of origin have a shorter desired length of stay.

To be without family attachments gives migrants more flexibility in their project and has lower costs; to be without a reunited family also allows migrants to easily reverse their decision (Dustmann 2003b; Erdal and Ezzati 2014). Similarly, not to show 'firm' intention ${ }^{4}$ such as applying for residence or learning the host country language could be signals of remigration intention, thus of a short stay (Waldinger 2008; Zaiceva and Zimmermann 2012). Even the lack of psychological attachments to host and home country could be interpreted as a signal of intention to reverse a migration decision (Carling and Pettersen 2014), entailing a temporary migration. These considerations lead us to our third hypothesis:

Hypothesis 3: Migrants with no attachments have a shorter desired length of stay in Italy.

Finally, the evaluation of migration experience matters. Thus, we hypothesise that expressing overall satisfaction for the context in emigration is positively associated with longer intention of stay, as stated by Mara and Landesmann (2013). Assuming that an aim of migration is to better economic conditions for the family across borders (host and origin country), we expected to have double association with migrants' intentions. On the one hand, economic difficulties could be a temporary condition attributable to an early stage of the migration or family reunion (Rimoldi and Barbiano di Belgiojoso 2014) associated with settlement intention; on the other hand, these conditions may reflect a real difficulty of integration into the host country labour market and therefore could be associated with the intention to leave the host country in a short time (Constant and Massey 2002; Jensen and Pedersen 2007; Venturini and Villosio 2008; Barbiano di Belgiojoso and Ortensi 2013; Mara and Landesmann 2013).

Hypothesis 4: Subjective migration evaluation (feeling) affects positively the desired length of stay in Italy while economic evaluation has a double association with it.

\section{Data, measurement and methods}

The analysis in the present study is based on data collected by a survey coordinated by the ISMU Foundation and conducted in 2008 and 2009 with more than 12,000 migrants aged 18 years or over, living in Italy at the time of the interview, with or without a residence permit, and coming from high emigration countries (for further details see Cesareo and Blangiardo 2009).

The sampling method used in the selection process was the Centre Sampling Technique (Baio et al. 2011), an approach used successfully in both Italian and European projects (e.g. Eurostat 2000; Huddleston and Dag Tjaden 2012). Surveys based on Centre Sampling are specifically designed to collect information on a representative sample of migrants, both legal and illegal. The method is based on a two-stage design. In the first stage, in order to guarantee a nationally representative sample, the 
interviews are allocated across Italian provinces and towns chosen by reference to their high incidence of migrants. In the second stage, a set of centres of aggregation-places where immigrants congregate such as phone centres, markets, places of worship and ethnic shops-is identified and in these places migrants are then randomly chosen for interview. In this survey, an appropriate procedure was introduced to avoid distortion due to the probability of a migrant being present in more than one centre. Interviews were performed face-to-face by interviewers with a foreign background, most of them cultural facilitators who had undergone specific training.

The survey, aimed at establishing the level of integration of the migrant population in Italy, collected data on the migration process (arrival time, intention of length of stay, etc.), household situation (living arrangements, presence of children, etc.) and the social and economic conditions of migrants.

We excluded from the analysis those migrants who were still in their original family (1509 cases) because their decision strongly depended on that of their parents.

These data about migrants' characteristics and degree of integration are new and very detailed and thus allow us to investigate new determinants of the migratory project, including decisions of illegal migrants for whom the data are generally scarce. However, the available dataset has some potential limitations for our study. Firstly, in this study, as in some previous studies (e.g. Coniglio et al., 2005; de Haas and Fokkema 2011), migrant's intentions are revealed and not the actual behaviour. However, this could not be considered a limitation here, since, as pointed out by some scholars, intentions are necessary and are even an interesting point of analysis (Waldorf 1995; King 2002; Zaiceva and Zimmermann 2008; Banfi and Boccagni 2011; de Haas and Fokkema 2011; Carling and Pettersen 2014). In fact, migration intentions are an appraisal of the migration plan, 'are significant in their own right: they represent summary attitudes to the migration experience' (Carling and Pettersen 2014, p. 14), and reflect migrants' attitude to the whole migration experience affecting behaviour such as investment in relationships and skills (Waldorf 1995; Carling and Pettersen 2014) even if intentions could remain unfulfilled. Moreover, several studies have confirmed that behaviour depends on intentions that are functions of attitudes towards that behaviour (Zaiceva and Zimmermann 2008 and reference therein) and that intentions are important for understanding migration decisions in the host country (Waldorf 1995). As a consistency check of migrants' intentions, it would be advisable to consider the "so-called "firm" migration intentions, actions such as learning a foreign language or applying for visas' (Zaiceva and Zimmermann 2012, p. 13). Hence, we introduced some of these firm migration intentions in the analysis.

Secondly, the available information is about migration intentions focusing on the desired length of stay in Italy through the question: 'How long do you think you'll stay in Italy?' with four possible answers: 'for ever,' 'for a long period,' 'for a short period' and 'I do not know'. This wording therefore does not permit us to distinguish between return and onward migrants, who, as briefly shown, have different reasons for the emigration. Hence, we focused on the settlement process by analysing the factors associated with different lengths of stay.

Third, due to the cross-sectional nature of the data, it is difficult to assess conclusions about the causality of the relationship between dependent and independent variables, thus we only considered the association between these, as done by previous studies (e.g. de Haas and Fokkema 2011; de Vroome and van Tubergen 2014). 


\section{Dependent variable}

We performed two logistic regression models:

Model 1 (indecision model) compares migrants with a plan for their future with undecided migrants; hence, for the dependent variable, we considered the categories 'for ever,' 'for a long period' and 'for a short period' as only one category 'having a plan' (coded 0 , reference) compared with the 'I do not know' (coded 1).

Model 2 (length of stay model), performed only among migrants with a future plan, compares migrants with different length of stay: 'for ever,' for a long period'(reference) ${ }^{5}$ and 'for a short period'.

These models were also performed separately for males and females. We have 8936 observations in the first model and 6494 in the second.

It should be noted that we considered two alternative procedures before deciding to implement two logistic regression models. More specifically, considering the nature of the variable desired length of stay, we firstly considered implementing an ordinal regression model. But we discarded this alternative since we found that the assumption of proportional odds was violated. Secondly, we tested a two-stage logistic regression model (TSLR) having at the first stage model 1 from which results were incorporated at the second stage into model 2 in order to take into account the possible selective effect of the undecided group. Implementing the TSLR model at the first stage, we obtained a value of the $\mathrm{ROC}=0.7$ indicating an acceptable but not excellent discriminant ability of the model (Hosmer et al. 2013); at the second stage, we found that the variable accounting for the indecision did not attain statistical significance; moreover, comparing the TSLR model with model 2, we found that the fit of the TSLR was not statistically better than the fit of model 2 . Therefore, we decided to implement model 1 and model 2 separately.

\section{Control and independent variables}

As control variables, we used age (expressed in years), gender (female versus male), education (degree versus other), the number of years since migration and country of origin. For the latter, we created nine dummy variables for the main representative citizenships: Albanian, Romanian, Chinese, Filipino, Senegalese (reference), Ukrainian, Tunisian, Polish and Moroccan.

In order to test our research hypotheses, we considered the following independent variables. We identified migrants with attachment (or location-specific capital) by reference to different types of attachments to Italy and country of origin.

First, for family attachments, we created two variables expressing both the existence of some members and their position across borders: one for the partner and the other for the children. Therefore, we constructed a variable 'partner' ${ }^{6}$ with three categories coded: 0 = 'have a partner in Italy' (reference, if migrant lives in Italy with the partner or the spouse), 1 = 'not have a partner' and 2 = 'have a partner abroad' (if migrant is married but non- cohabiting in Italy), and a variable 'children' with three categories coded: 0 = 'have all children in Italy' (reference), 1 = 'not have children' and 2 = 'have at least one child abroad'. 
Second, political attachments to Italy were measured by permission to stay status. We introduced a three-level categorical variable for permission to stay status: 1 = 'regu$\operatorname{lar}^{7}$ and resident' (reference); 2 = 'regular but not resident' and 3 = 'undocumented'.

Third, economic attachments to Italy were measured by homeownership, labour market participation and bank account, while the economic attachments to the country of origin were measured by the remittance. From the tenure variable, we constructed a dummy variable for homeownership with the reference category non-homeownership. We introduced an indicator for labour market participation coded $0=$ 'unstably, irregularly employed or unemployed' (reference), 1 = 'stably employed' and 2 = 'non-active'. The bank account variable is coded: 1 = 'yes' if one of the family members has a bank account in Italy, $0=$ 'no' (reference). The remitting of money is measured by a three-level variable coded $0=$ 'never' (reference), $1=$ 'regularly' and $2=$ 'sometimes/ in case of need'.

Fourth, socio-cultural attachments were measured by four variables: the citizenship composition of their social networks, high degree of approval for the Italian lifestyle, their use of the Italian language at home and good proficiency in Italian. The first variable has four categories: 1 = 'only foreigners' (reference), 2 = 'more foreigners than Italians', 3 = 'Italians and foreigners equally' and $4=$ 'more Italians than foreigners'. High degree of approval for the Italian lifestyle is a dummy variable, 1 = 'yes' and $0=$ 'no' (reference), and refers to different dimensions: food, education, work, clothing, free time and family relationships. The median of the score of the six corresponding items on a Likert scale $(0=$ 'very low' up to $5=$ 'very high' and assigning 0 to ' $\mathrm{I}$ do not know this aspect') was calculated, and if the median score was 4 or more, the migrant was considered to have a high degree of approval. We constructed a dummy variable measuring the frequency of use of Italian at home and with the family: 1 = 'high frequency' and $0=$ 'other' (reference). Good proficiency in Italian was rated from the self-declared level of speaking, registered on scale $(0=$ 'very low' up to $5=$ 'very high') coded $1=$ 'yes' (if migrants declared 4 or 5 ) and $0=$ 'no' (reference).

Fifth, we introduced psychological attachment considering the 'double loyalties' issue, by constructing a synthetic indicator 'loyalties' moving from the two variables expressing respectively sense of belonging to Italy ('belong to Italy') and host country ('belong to home') on a Likert scale $(0=$ low up to $3=$ high). The variable has four categories: $0=$ 'higher sense of belonging to the country of origin' (reference) if 'belong to Italy' equals 0 or 1 , while 'belong to home' equals 2 or 3 ; 1 = 'not belong' if both variables are lower than 2; 2 = 'higher sense of belonging to Italy' if 'sense of belonging to Italy' equals 2 or 3 while 'belong to home' equals 0 or 1 and 3 = 'high sense of belonging to both' if 'belong to Italy' and 'belong to home' both equal 2 or 3 .

Finally, to test our fourth hypothesis, we considered two dimensions: the personal feelings about being in the host country (subjective dimension) and the family's ability to save $^{8}$ (economic dimension). For the first variable, we created from the variable feeling in Italy, revealed on a Likert scale ( 1 = very well to $5=$ very badly), a dummy variable 1 = 'feeling very well' versus 0 = 'other' (reference category). The second variable has three categories: 1 = 'saving every month' (reference group), 2 = 'spending all the income' and 3 = 'the income is not enough'. 


\section{Results}

\section{A brief description of population and context}

The first question for the data concerns intentions. While $48.5 \%$ of all the migrants surveyed wished-sooner $(12.5 \%)$ or later $(36 \%)$-to leave Italy, nearly $24 \%$ thought they would settle in Italy permanently. However, a considerable proportion of migrants were undecided: one in three had not yet planned the length of their stay in Italy (similarly to de Haas and Fokkema 2011 and de Vroome and van Tubergen 2014).

In order to give a complete picture of the migrant population living in Italy, let us consider its most important characteristics comparing migrants with and without future plans. Table 1 provides descriptive statistics by percentage according to future plan for Italy in year 2008-2009.

As shown in Table 1, there is a slight prevalence of males (51\%) and almost all the migrants were born abroad. Eastern Europeans are the most represented (38 \%). As regards family situations, those with a partner more frequently live with him/her in Italy; however, there are many migrants without a partner (36.5\%). The majority of migrants do not have any children, one out of three lives in Italy with all the children, while nearly one out of four has at least one child abroad.

Looking at migrants' economic circumstances, we can see that the majority of migrants have a good job status with a regular job although a significant proportion are less fortunate: $28.4 \%$ are irregularly employed or unemployed or casual workers. A total of $18.5 \%$ have degrees.

The mean length of stay is 8.2 years, with only $6.8 \%$ of migrants having arrived during the last 12 months (2007-2008); nearly $26 \%$ had been living in Italy for more than 10 years. Regarding their residency status, it is noticeable that the majority had a regular permit and residence while $12 \%$ did not have a regular permit.

However, Table 1 also shows some differences between migrants with and without a plan. Migrants without a future plan are usually younger, more frequently male, without a family, more frequently undocumented and irregularly or unstably employed coming from Africa.

\section{Indecision}

Table 2 presents odds ratios (ORs) and significance from the logistic regression models (baseline 'migrants with future plan'). According to our indecision model, females are more undecided about the future. Indecision is associated with both family location across border and existence of some family members. The lack of partner or children or the absence of children in emigration are positively associated with indecision even though differently for men and women: while women seem more inclined to indecision only in the case of no children, men only in the case of no partner. Moreover, the indecision is positively associated with negative balance of the migration experience indicated by the inability to save money and bad feeling in Italy, migrants question their plan in case of economic difficulties or in case of dissatisfaction with their experience, as highlighted by Zaiceva and Zimmermann (2012) adopting a 'wait and see' behaviour without a determined plan. The more educated are more likely to be determined about the future. There is an inverted U-shape relation between indecision and years since 
Table 1 Descriptive statistics of migrants living in Italy according to future plan (percent), 2008-2009

\begin{tabular}{|c|c|c|c|}
\hline & All & Undecided migrants & $\begin{array}{l}\text { Migrants with } \\
\text { future plan }\end{array}$ \\
\hline Male & 51.0 & 52.1 & 50.5 \\
\hline \multicolumn{4}{|l|}{ Age } \\
\hline $18-24$ & 7.8 & 8.5 & 7.5 \\
\hline $25-34$ & 36.6 & 41.0 & 34.8 \\
\hline $35-44$ & 31.9 & 30.0 & 32.7 \\
\hline $45+$ & 23.7 & 20.5 & 25.1 \\
\hline Country of birth: abroad & 99.7 & 99.7 & 99.6 \\
\hline \multicolumn{4}{|l|}{ Area of origin } \\
\hline Eastern Europe & 38.2 & 35.8 & 39.3 \\
\hline Asia & 17.9 & 17.7 & 18.0 \\
\hline North Africa & 17.4 & 19.4 & 16.6 \\
\hline Other African countries & 17.6 & 19.2 & 17.0 \\
\hline Latin America & 8.8 & 8.0 & 9.1 \\
\hline \multicolumn{4}{|l|}{ Partner } \\
\hline Partner in Italy & 47.3 & 41.2 & 49.9 \\
\hline Partner abroad & 16.2 & 17.0 & 15.9 \\
\hline No partner & 36.5 & 41.8 & 34.3 \\
\hline \multicolumn{4}{|l|}{ Children } \\
\hline All children in Italy & 33.5 & 28.5 & 35.6 \\
\hline At least one child abroad & 24.8 & 25.1 & 24.7 \\
\hline No children & 41.7 & 46.4 & 39.7 \\
\hline \multicolumn{4}{|l|}{ Legal status } \\
\hline Regular and resident & 80.0 & 76.7 & 81.4 \\
\hline Regular but not resident & 8.0 & 8.6 & 7.8 \\
\hline Undocumented & 12.0 & 14.7 & 10.9 \\
\hline \multicolumn{4}{|l|}{ Length of stay (years) } \\
\hline $0-1$ & 6.8 & 7.1 & 6.8 \\
\hline $2-4$ & 24.4 & 28.3 & 22.8 \\
\hline $5-10$ & 42.3 & 42.0 & 42.5 \\
\hline $11+$ & 26.4 & 22.6 & 28.0 \\
\hline \multicolumn{4}{|l|}{ Professional status } \\
\hline Unstably or irregularly employed & 28.4 & 32.6 & 26.7 \\
\hline Stably employed & 61.2 & 57.0 & 62.9 \\
\hline Non-active & 10.5 & 10.4 & 10.5 \\
\hline Degree & 18.5 & 19.7 & 15.9 \\
\hline
\end{tabular}

Source: elaboration on ISMU data

migration among men: the indecision is more likely in an intermediate phase of the migration. This is probably because at the beginning migrants have a clear plan (even if they change it later) while after they have been in emigration a longer number of years, they have better information on which to decide on a more precise plan.

Conversely, to have a plan for the future is positively associated with economic attachments to both country of origin (remitting every month) and the host country 
Table 2 Odds ratios and significance from the logistic regression models dependent variable plan for the future (baseline 'migrants with future plan')

\begin{tabular}{|c|c|c|c|}
\hline & All & Female & Male \\
\hline Age & 0.999 & 0.975 & 1.033 \\
\hline Age squared & 0.999 & 1.000 & 0.999 \\
\hline Years since migration & $1.040^{* *}$ & 1.017 & $1.067^{* *}$ \\
\hline Years since migration squared & $0.999^{*}$ & 0.999 & $0.998^{*}$ \\
\hline Female (ref male) & $1.175^{* *}$ & & \\
\hline \multicolumn{4}{|l|}{ Citizenship (ref Senegalese) } \\
\hline Romanian & 0.920 & 0.975 & 1.154 \\
\hline Albanian & 0.869 & 1.068 & 0.855 \\
\hline Chinese & $0.638^{* *}$ & 0.945 & $0.487^{* * *}$ \\
\hline Filipino & 1.070 & 1.357 & 1.025 \\
\hline Moroccan & 1.008 & 1.539 & 0.894 \\
\hline Ukrainian & 0.825 & 0.942 & 0.978 \\
\hline Tunisian & 0.797 & 1.291 & 0.733 \\
\hline Polish & 0.725 & 0.747 & 1.098 \\
\hline Other & 0.857 & 0.981 & 0.889 \\
\hline Degree (ref other) & $0.875^{*}$ & 0.989 & 0.824 \\
\hline \multicolumn{4}{|l|}{ Children (ref all children in Italy) } \\
\hline No children & $1.159^{*}$ & $1.240^{*}$ & 1.042 \\
\hline At least one child abroad & $1.178^{*}$ & 1.154 & 1.240 \\
\hline \multicolumn{4}{|l|}{ Partner (ref partner in Italy) } \\
\hline Partner abroad & 1.144 & 1.244 & 1.089 \\
\hline No partner & $1.224^{* *}$ & 1.150 & $1.497^{* * *}$ \\
\hline \multicolumn{4}{|l|}{ Legal status (ref regular and resident) } \\
\hline Regular but not resident & 0.948 & 0.955 & 0.925 \\
\hline Undocumented & 1.128 & 1.161 & 1.132 \\
\hline \multicolumn{4}{|l|}{ Friendship (ref all foreigners) } \\
\hline More foreigners than Italians & $0.839^{*}$ & 0.914 & $0.789^{*}$ \\
\hline Italian and foreigners equally & $0.840^{*}$ & 0.849 & 0.837 \\
\hline More Italians than foreigners & $0.763^{* *}$ & 0.866 & $0.668^{* *}$ \\
\hline Proficiency in Italian & 1.015 & 1.012 & 1.037 \\
\hline High degree of approval for the Italian lifestyle & $0.780^{* * *}$ & $0.838^{*}$ & $0.722^{* * *}$ \\
\hline Frequent use of Italian at home (ref other) & 0.888 & 0.903 & 0.923 \\
\hline \multicolumn{4}{|l|}{ Professional status (ref stably employed) } \\
\hline Unstably or irregularly employed & 0.974 & 0.969 & 0.999 \\
\hline Non-active & 0.985 & 0.965 & 0.850 \\
\hline Homeownership (ref other) & 0.864 & $0.728^{* *}$ & 1.078 \\
\hline Bank account owner & 1.092 & 1.104 & 1.089 \\
\hline \multicolumn{4}{|l|}{ Remitting (ref never) } \\
\hline Every month & $0.795^{* *}$ & $0.755^{*}$ & 0.837 \\
\hline Sometimes/in case of need & 0.970 & 0.989 & 0.944 \\
\hline \multicolumn{4}{|c|}{ Loyalties (ref higher attachment to the origin country) } \\
\hline No attachment & 0.985 & 0.884 & 1.072 \\
\hline Higher attachment to Italy & $0.370^{* * *}$ & $0.278^{* * *}$ & $0.497^{* * *}$ \\
\hline
\end{tabular}


Table 2 Odds ratios and significance from the logistic regression models dependent variable plan for the future (baseline 'migrants with future plan') (Continued)

\begin{tabular}{llll}
\hline High attachment to both country & $0.704^{* * *}$ & $0.665^{* * *}$ & $0.727^{* * *}$ \\
Feeling very well in Italy (ref other) & $0.577^{* * *}$ & $0.586^{* * *}$ & $0.573^{* * *}$ \\
Ability to save (ref save every month) & & & \\
Spending all the income & $1.172^{*}$ & 1.178 & 1.191 \\
Difficulty in making ends meet & $1.141^{*}$ & 1.174 & 1.139 \\
Number & 8936 & 4342 & 4594 \\
\hline
\end{tabular}

Source: elaboration on ISMU data

${ }^{*} p<0.05 ;{ }^{* *} p<0.01$ and ${ }^{* * *} p<0.001$

(own a home) and to the socio-cultural attachments (high degree of approval for Italian lifestyle, frequent use of Italian at home and (though only for men) to have a network with more Italians). Moreover, to have a stronger sense of belonging to Italy or equally strong for Italy and home is positively associated with having a plan.

Legal and occupational status, age and proficiency in speaking Italian do not affect the decision-making process. As for the country of origin, only Chinese has a lower indecision compared to Senegalese; for the other citizenships, there is no significant evidence.

Hence, our Hypothesis 1 is overall supported by the results: indecision is associated with an intermediate phase of migration at the early stage of family in the case of unfavourable balance of the migration experience.

\section{Length of stay}

Table 3 shows odds ratios and significances from the multinomial logistic regression models (baseline 'for a long time').

Table 3 shows that if women are more undecided than men, they are more likely to intend to stay for a long time compared to other alternatives. A short-term stay is more likely compared to long-term among both the youngest and oldest, thus before the family formation and after retirement, confirming previous results (Mara and Landesmann 2013; Erdal and Ezzati 2014).

Years since migration are partially associated with the desired length of stay: as more time passes since migration, women are more inclined to stay 'forever' than 'for a long time'. This result may be attributable to the presence in the model of some variable indicators of attachments to the host country which in turn are functions of time (de Haas and Fokkema 2011). Performing a model without these variables, there emerges a positive relationship between desired length of stay and years since migration: the more years migrants stay, the more likely they intend to stay longer.

Some differences emerge considering the citizenship: all except Romanian, Chinese and Filipino have a higher propensity to settlement compared to the Senegalese. Romanians are more inclined both to settle and to stay for a short time. These results indicate that migrants' intentions are affected not only by migrants' characteristics but also by the origin background. Graduates more often declared the intention to stay a shorter time in Italy, confirming previous results (Da Vanzo 1983; Mara and Landesmann 2013).

Confirming our Hypotheses $2 \mathrm{a}$ and $2 \mathrm{~b}$, attachments to Italy affect the desired length of stay in Italy. More specifically, the socio-cultural attachments are strongly and 
Table 3 Odds ratios and significance from the multinomial logistic regression models dependent variable length of stay (baseline 'for a long time')

\begin{tabular}{|c|c|c|c|c|c|c|}
\hline & \multicolumn{3}{|l|}{ For ever } & \multicolumn{3}{|c|}{ For a short period } \\
\hline & All & Female & Male & All & Female & Male \\
\hline Age & 0.977 & 1.001 & 0.939 & $0.930^{* *}$ & $0.916^{*}$ & 0.934 \\
\hline Age squared & 1.000 & 0.999 & 1.001 & $1.001^{*}$ & $1.001^{*}$ & 1.001 \\
\hline Years since migration & $1.038^{*}$ & $1.068^{* *}$ & 1.015 & 1.034 & 0.999 & 1.065 \\
\hline Years since migration squared & 0.999 & 0.999 & 1.000 & 0.999 & 0.999 & 0.999 \\
\hline Female (ref male) & $0.841^{*}$ & & & $0.772^{* *}$ & & \\
\hline \multicolumn{7}{|l|}{ Citizenship (ref Senegalese) } \\
\hline Romanian & $1.732^{* *}$ & 2.910 & 1.412 & $1.647^{* *}$ & 1.795 & 1.536 \\
\hline Albanian & $2.452^{* * *}$ & $3.658^{*}$ & $2.423^{* * *}$ & 0.912 & 1.236 & 0.808 \\
\hline Chinese & 1.315 & 1.936 & 1.423 & 0.645 & 0.658 & 0.619 \\
\hline Filipino & 1.112 & 1.946 & 0.880 & 0.409 & 0.485 & 0.315 \\
\hline Moroccan & $3.149^{* * *}$ & $4.479^{* *}$ & $3.113^{* * *}$ & 1.065 & 1.168 & 1.048 \\
\hline Ukrainian & $1.833^{* *}$ & $3.147^{*}$ & 0.979 & 1.215 & 1.388 & 0.902 \\
\hline Tunisian & $2.071^{* *}$ & 1.942 & $2.183^{* *}$ & 1.130 & 0.932 & 1.104 \\
\hline Polish & $1.689^{*}$ & 2.277 & 2.435 & 1.612 & 1.619 & 2.313 \\
\hline Other & $2.148^{* * *}$ & $3.382^{*}$ & $1.995^{* * *}$ & 1.083 & 1.242 & 0.999 \\
\hline Degree (ref other) & 0.902 & 0.886 & 0.947 & $1.486^{* * *}$ & 1.192 & $1.778^{* * *}$ \\
\hline \multicolumn{7}{|l|}{ Children (ref all children in Italy) } \\
\hline No children & 0.939 & 0.845 & 1.063 & $1.505^{* * *}$ & 1.102 & $2.115^{* * *}$ \\
\hline At least one child abroad & 0.958 & 0.938 & 0.943 & $1.636^{* * *}$ & 1.278 & $2.162^{* * *}$ \\
\hline \multicolumn{7}{|l|}{ Partner (ref partner in Italy) } \\
\hline Partner abroad & 0.858 & $0.659^{*}$ & 0.896 & $1.354^{*}$ & $1.658^{* *}$ & 1.012 \\
\hline No partner & 0.894 & 0.881 & $0.758^{*}$ & 1.016 & 1.193 & 0.762 \\
\hline \multicolumn{7}{|l|}{ Professional status (ref stably employed) } \\
\hline Unstably or irregularly employed & $1.383^{* * *}$ & 1.094 & $1.649^{* * *}$ & 1.117 & 1.074 & 1.299 \\
\hline Non-active & $1.419^{* *}$ & $1.572^{* * *}$ & 0.701 & $1.863^{* * *}$ & $1.633^{*}$ & $2.376^{* *}$ \\
\hline \multicolumn{7}{|l|}{ Legal status (ref regular and resident) } \\
\hline Regular but not resident & 0.915 & 0.854 & 1.035 & $1.621^{* * *}$ & $1.599^{*}$ & $1.656^{* *}$ \\
\hline Undocumented & 1.256 & 1.287 & 1.100 & $1.602^{* * *}$ & $1.670^{*}$ & $1.541^{*}$ \\
\hline \multicolumn{7}{|l|}{ Friendship (ref all foreigners) } \\
\hline More foreigners than Italians & 0.907 & 0.966 & 0.921 & $0.766^{*}$ & 0.794 & 0.760 \\
\hline Italian and foreigners equally & 1.233 & 1.370 & 1.227 & $0.757^{*}$ & $0.647^{*}$ & 0.862 \\
\hline More Italians than foreigners & $1.812^{* * *}$ & $2.115^{* * *}$ & $1.696^{* *}$ & $0.730^{*}$ & 0.713 & 0.797 \\
\hline Feeling very well in Italy (ref other) & $2.244^{* * *}$ & $2.256^{* * *}$ & $2.249^{* * *}$ & $0.792^{*}$ & $0.716^{*}$ & 0.902 \\
\hline Homeownership (ref other) & $1.891^{* * *}$ & $1.991^{* * *}$ & $1.603^{* * *}$ & 0.832 & 0.744 & 1.034 \\
\hline \multicolumn{7}{|l|}{ Ability to save (ref save every month) } \\
\hline Spending all the income & 0.956 & 1.011 & 0.905 & 1.029 & 0.901 & 1.212 \\
\hline Difficulty in making ends meet & $1.178^{*}$ & 1.152 & 1.172 & $1.290^{* *}$ & 1.140 & $1.526^{* *}$ \\
\hline \multicolumn{7}{|l|}{ Remitting (ref never) } \\
\hline Every month & $0.524 * * *$ & $0.511^{* * *}$ & $0.534^{* * *}$ & $1.316^{*}$ & 1.141 & $1.437^{*}$ \\
\hline Sometimes/in case of need & $0.689^{* * *}$ & $0.734^{* *}$ & $0.654^{* * *}$ & 0.985 & 0.727 & 1.215 \\
\hline Bank account owner & $1.151^{*}$ & 1.184 & 1.122 & 0.903 & 0.849 & 0.999 \\
\hline
\end{tabular}


Table 3 Odds ratios and significance from the multinomial logistic regression models dependent variable length of stay (baseline 'for a long time') (Continued)

\begin{tabular}{lllllll}
\hline Loyalties (ref higher attachment to the origin country) & & & & & \\
No attachment & $3.100^{* * *}$ & $3.47^{* * *}$ & $2.837^{* * *}$ & 1.011 & 0.709 & 1.354 \\
Higher attachment to Italy & $4.351^{* * *}$ & $4.584^{* * *}$ & $4.345^{* * *}$ & $0.242^{* * *}$ & $0.173^{* * *}$ & $0.349^{*}$ \\
High attachment to both Country & $1.595^{* * *}$ & $1.625^{* * *}$ & $1.628^{* * *}$ & $0.397^{* * *}$ & $0.362^{* * *}$ & $0.425^{* * *}$ \\
Proficiency in Italian & 0.955 & 0.946 & 0.980 & 1.146 & 1.108 & 1.122 \\
High degree of approval for the Italian lifestyle & $1.251^{* * *}$ & 0.978 & $1.543^{* * *}$ & $0.702^{* * *}$ & $0.731^{* *}$ & $0.693^{* * *}$ \\
Frequent use of Italian at home (ref other) & $1.404^{* * *}$ & $1.600^{* * *}$ & 1.185 & $1.253^{*}$ & $1.294^{*}$ & 1.024 \\
Number & 6494 & 3137 & 3257 & & & \\
\hline
\end{tabular}

Source: elaboration on ISMU data

${ }^{*} p<0.05 ;{ }^{* *} p<0.01$ and ${ }^{* *} p<0.001$

positively associated with settlement intention: migrants having mainly natives among friends and therefore having invested in relationships, approving Italian lifestyle and using Italian more frequently at home, more often expressed the intention to settle, confirming previous results (Carling and Erdal 2014; de Vroome and van Tubergen 2014).

As for the economic attachments, the family ability to save or economic difficulties do not affect the settlement intention, but they are negatively associated with a shortterm migration. Homeownership and bank account-considered as forms of saving-are positively associated with settlement intention, as stated by numerous studies (Da Vanzo 1983; Constant and Massey 2002, 2003; Bastia 2011; Delpierre and Verheyden 2014). The relationship between professional status and desired length of stay reflects gender roles. While non-active men are more likely to intend to stay for a short time once finishing their studies or having retired (confirming previous results), non-active women are more inclined to intend to both settle and to stay for a short time compared to those stably employed. This apparent contradiction could be correctly explained by the fact that non-active women are mainly housewives with families who follow their husband and thus intend to stay in Italy 'for ever' despite the lack of an income. Moreover, men unstably or irregularly employed more often declared permanent migration intention.

As for family attachments to the host country, having their partner or all children in Italy are both strongly associated with settlement intention. Nevertheless, nothing could be said about the causality of this relationship, because the family reunion is likely to mirror migrants' intentions (de Haas and Fokkema 2011).

Unsurprisingly, legal status does not affect the settlement intention.

Finally, considering psychological attachments, as expected, higher sense of belonging to Italy is positively and strongly associated with settlement intention. It should be noted that double loyalty (high attachment to both countries) is positively associated with both settlement and long period; as stated by Waldinger (2008), frequently the home country loyalty appears to have a 'symbolic quality' without necessarily leading to return home.

Confirming our Hypothesis $2 \mathrm{~b}$ and Hypothesis 3, attachments to country of origin and no attachments are associated with shorter stay. Thus, as for family attachments, to have at least one child abroad or to have a partner abroad increases the likelihood of temporary (short or long) migration respectively among men and women. Once more, the role of the partner is differentiated along gender lines: while migrants' intentions are strongly associated with partners' decisions among women, this is not the case for 
men, confirming previous results (Mara and Landesmann 2013). As for economic and psychological attachments, both remitting and higher sense of belonging to the country of origin are associated with temporary migration intention.

The lack of attachments either to host and home country is associated with a shorter desired length of stay, as expected: not having children and not having a partner are associated with higher likelihood of a temporary migration, although only for men. Nonresident or undocumented migrants more often expressed the intention to stay for a short period. Contrary to expectation, no sense of belonging to either host or home country is associated with settlement intention. It should be noted that proficiency in Italian does not affect migrants' intentions.

Finally, as expected, a positive balance of the migration experience has a double effect: while the subjective dimension (feeling well in Italy) is strongly associated with settlement intention or long stay, the economic consideration about family ability to save indicates that migrants reporting the worst economic circumstances-that is whose monthly income does not cover all spending needs-have higher intention to both settlement and short stay. These results can be interpreted in two opposite ways, both of which are supported by evidence from other studies. Firstly, our results support the hypothesis of negative selection in remigration pointed out by the aforementioned studies about migrant assimilation in the Italian labour market (Venturini and Villosio 2008; Dell'Aringa and Pagani 2011; Strom et al. 2013). Secondly, they highlight the effects of the family reunification and settlement process on family economic conditions: the presence of a completely reunified family entails a temporary status of poverty due to the growth of family size and assimilation with the Italian lifestyle necessitating extra spending (Barbiano di Belgiojoso et al. 2009; Rimoldi and Barbiano di Belgiojoso 2014).

\section{Conclusions}

The decision to emigrate from the country of origin may not be a permanent one: migrants may decide to return home or to remigrate to a third country. This phenomenon, established for some time in certain other European countries, has become an important one for Italy only recently (Blangiardo 2012). As demonstrated in this paper, only a minority of migrants intend to stay permanently in the host country, while among those who have a clear plan for their future, only one third of migrants seem to think of their migration to Italy as permanent. Hence, it is important to reflect on migrants' future intentions, since, even if sometimes, migrants change plans over the migration and become established in the host country whether or not that is their plan (Waldinger 2008), their intentions affect their behaviour (e.g. investment in relationship, skills) and decisions in the host country (Waldorf 1995; Carling and Erdal 2014).

This paper contributed to the knowledge of migrants' intentions in two ways: first, it analysed the factors associated with indecision about future plans, usually a neglected issue; second, it focused on the desired length of stay and its relationship with attachments to host and home country.

If, according to our results, indecision seems to be associated with an intermediate phase of migration at the early stage of family in case of negative balance of the migration experience, the desired length of stay usually reflects the mix of attachments to home and host country. Among all attachments, psychological ones and the subjective dimension of the migration experience balance have the strongest positive association 
to the desired length of stay. The economic attachments to the host country have a double effect, as frequently highlighted (e.g. Carling and Pettersen 2014), indicating the existence of a multiple migration process. The lack of attachments was usually associated with shorter desired length of stay.

Finally, even though gender role in migrants' intentions was not the focus of this paper, our results highlight the importance of that role as stated by previous results (Mara and Landesmann 2013; Ortensi and Barbiano di Belgiojoso 2015), indicating that gender role in this context deserves further research.

\section{Endnotes}

${ }^{1}$ Sometimes, these options are combined, generating circular migrations and repeated back and forth movements. The phenomenon was highlighted in the special issue recently published on International Migration (Carling and Erdal 2014).

${ }^{2}$ See "Data, measurement and methods" for a discussion.

${ }^{3}$ However, some interesting results on a negative selection effect in the foreign population living in Italy were highlighted by a number of investigations concerning migrant assimilation in the Italian labour market (Strom et al. 2013; Dell'Aringa and Pagani 2011).

${ }^{4}$ See next section for further details.

${ }^{5}$ After considering other possibilities, we chose this intermediate alternative as reference in order to allow us to compare directly migrants with short and long periods (that we hypothesise to have different strategies) and to have an easier interpretation of the results.

${ }^{6}$ It was constructed combining the variables civil status ('single,' 'married', 'widow' or 'separated') and family member in emigration ('single,' 'single parent', 'couple with children', 'couple without children', 'relatives and friends without children,' 'relatives and friends with children' and eventually additional members). Category 'have a partner in Italy' includes both partner and spouse because they were revealed together, while for the other categories we could not include cohabiting couples due to the lack of information.

${ }^{7}$ The category 'regular' includes all forms of sojourn permission and Italian citizenship.

${ }^{8}$ We prefer to use this variable (a family variable) as the economic indicator rather than personal income because the latter does not correctly reflect the economic condition of a family where there are two or more workers.

\section{Acknowledgments}

I would like to thank the anonymous referees for their insightful comments and suggestions and the ISMU

Foundation for providing me with the dataset.

Competing interests

The author declares that she has no competing interests.

Received: 12 November 2014 Accepted: 8 March 2016

Published online: 14 July 2016

References

Ahlburg, D. A., \& Brown, R. P. C. (1998). Migrants' intentions to return home and capital transfers: a study of Tongans and Samoans in Australia. The Journal of Development Studies, 35(2), 125-151.

Ahrens, J., Kelly, M., \& vam Liempt, I. (2014). Free movement? the onward migration of EU citizens born in Somalia, Iran, and Nigeria. Population Space and Place. doi:10.1002/psp.1869.

Anniste, K. \& Tammaru, T. (2014). Ethnic differences in integration levels and return migration intentions: a study of Estonian migrants in Finland. Demographic Research, 30(13), 377-412. 
Baio, G., Blangiardo, G. C., \& Blangiardo, M. (2011). Centre sampling technique in foreign migration surveys: a methodological note. Journal of Official Statistics, 27(3), 451-465.

Banfi, L., \& Boccagni, P. (2011). Transnational family life and female migration in Italy: one or multiple patterns? In A. Kraler, E. Kofman, M. Kohli, \& C. Schmoll (Eds.), Gender, generations and family in the international migration (pp. 287-312). Amsterdam: Amsterdam University Press.

Barbiano di Belgiojoso, E., Chelli, F. M., \& Paterno, A. (2009). Povertà e standard di vita della popolazione straniera in Lombardia. Rivista Italiana di Economia Demografia e Statistica, LXIII(3-4), 23-30.

Barbiano di Belgiojoso, E., \& Ortensi, L. E. (2013). Should I stay or should I go? The case of Italy. Rivista Italiana di Economia, Demografia e Statistica, LXVII(3/4), 31-38.

Bastia, T. (2011). Policy arena. Should I stay or should I Go? Return migration in time of crises. Journal of International Development, 23, 583-595.

Benton, M., \& Petrovic, M. (2013). How free is free movement? dynamics and drives of mobility within european union. Brussels: Migration Policy Institute.

Black, R., Koser, K., Munk, K., Alfied, G., D'onofrio, L., \& Tiemoko, R. (2004). Understanding voluntary return (Research Online Report 50/04). Falmer: Sussex Centre for Migration Research.

Blangiardo, G. C. (2012). Se tre indizi (statistici) possono fare una prova. II Sole 24 Ore, May 21.

Borjas, G. J., \& Bratsberg, B. (1996). Who leaves? The outmigration of the foreign-born. Review of Economics and Statistics, 78(1), 165-176.

Borodak, D., \& Tichit, A. (2013). Should we stay or should we go? Irregular migration and duration of stay: the case of Moldovan migrants. Migration Studies. doi:10.1093/migration/mnt016.

Carling, J., \& Erdal, M. B. (2014). Connections between return migration and transnationalism. International Migration, 52(6), $1-12$.

Carling, J., \& Pettersen, S. V. (2014). Return migration intentions in the integration-transnationalism matrix. International Migration, 52(6), 13-30.

Carrión-Flores, C. E. (2006). What makes You Go back home? Determinants of the duration of migration of Mexican immigrants in the United States. Mimeo: The University of Arizona.

Cassarino, J. P. (2004). Theorising return migration: the conceptual approach to return migrants revisited. International Journal on Multicultural Societies, 6(2), 253-279.

Castagnone, E. (2011). Building a comprehensive framework of African migrations patterns: the case of migration between Senegal and Europe, graduate school in social, economic and political sciences (Phd Thesis).

Cela, E., Fokkema, T., \& Ambrosetti, E. (2013). Variation in transnationalism among Eastern European migrants in Italy: the role of duration of residence and integration. Southeast European and Black Sea Studies, 13(2), 159-209.

Cerase, F. (1974). Expectations and reality: a case study of return migration from the United States to Southern Italy. International Migration Review, 8(2), 245-262.

Cesareo, V., \& Blangiardo, G. C. (2009). Indici di integrazione. Un'indagine empirica nella realtà migratoria italiana. Milano: Franco Angeli.

Coniglio, N., De Arcangelis, G., \& Serlenga, L. (2009). Return intentions of irregular migrants and skills: the perverse effect of the brain waste. Review of Development Economics, 13(4), 641-657.

Constant, A., \& Massey, D. S. (2002). Return migration by German guest workers: neoclassical to new economic theories. International Migration, 40(4), 5-38.

Constant, A., \& Massey, D. S. (2003). Self-selection, earnings, and out-migration: a longitudinal study of immigrants to Germany. Journal of Population Economics, 16, 631-653.

Constant, A., \& Zimmermann, K. F. (2011). Circular migration and repeat migration: counts of exits and years away from the host country. Population Research and Policy Review, 30, 495-515.

Da Vanzo, J. (1976). Differences between return and non return migration: an econometric analysis. International Migration Review, 10(1), 13-27.

Da Vanzo, J. (1983). Repeat migration in the United States: who moves back and who moves on? Review of Economics and Statistics, 65, 552-559.

de Haas, H., \& Fokkema, T. (2011). The effects of integration and transnational ties on international return migration intensions. Demographic Research, 25(24), 755-782.

De Vroome, T., \& Van Tubergen, F. (2014). Settlement intentions of recently arrived Immigrants and refugees in the Netherlands. Journal of Immigrant and Refugees Studies, 12(1), 47-66.

Dell'Aringa, C., \& Pagani, L. (2011). Labour market assimilation and over-education: the case of immigrant workers in Italy. Economia Politica, 2, 219-240.

Delpierre, M., \& Verheyden, B. (2014). Remittances, savings and return migration under uncertainty. Journal of Migration, 3, 1-22.

Diehl, C., \& Liebau, E. (2015). Turning back to turkey—or turning the back on Germany? Zeitschrift fur Soziologie, $44(1), 22-41$.

Dustmann, C. (2001). Return migration, wage differentials, and the optimal migration duration (Discussion Paper Series, IZA, 264).

Dustmann, C. (2003a). Return migration, wage differentials and the optimal migration duration. European Economic Review, 47(2), 353-69.

Dustmann, C. (2003b). Children and return migration. Journal of Population Economics, 16, 815-830.

Dustmann, C., \& Mestres, J. (2010). Remittances and temporary migration. Journal of Development Economics, 92, 62-70.

Dustmann, C., \& Weiss, Y. (2007). Return migration: theory and empirical evidence from the UK. British Journal of Industrial Relations, 45(2), 236-256.

Erdal, M. B., \& Ezzati, R. (2014). Where are you from' or 'when did you come?' Temporal dimensions in migrants' reflections about settlement and return. Ethnic and Racial Studies. doi:10.1080/01419870.2014.971041.

Eurostat. (2000). Push and pull factors of international migration. A comparative report, theme 1 general statistics, European communities. 
Evergeti, V., \& Ryan, L. (2011). Negotiating transnational caring practices among migrant families. In A. Kraler, E. Kofman, M. Kohli, \& C. Schmoll (Eds.), Gender, generations and family in the international migration (pp. 355-373). Amsterdam: Amsterdam University Press.

Gmelch, G. (1980). Return migration. Annual Review of Anthropology, 9, 135-159.

Haandrikman, K., \& Hassanen, S. (2014). Onward migration of African Europeans: comparing attitudes to migration motives. Stockholm Research Reports in Demography, 15, 34

Hill, J. K. (1987). Immigrant decisions concerning duration of stay and migratory frequency. Journal of Development Economics, 25, 221-234.

Hosmer, D. V., Lemeshow, S., \& Sturdivant, R. X. (2013). Applied logistic regression, third edition (Wiley Series in Probability and Statistics).

Hou, F., \& Beaujot, R. (1994). The differentiation of determinants among return, onward, primary migrants in Canada. Canadian Studies in Population, 21(1), 1-19.

Huddleston, T, Dag Tjaden, J. (2012). Immigrant Citizens Survey, King Baudouin Foundation and Migration Policy Group Bruxelles. Access in June 2013

Jefrey, L., \& Murison, J. (2011). Guest editorial. The temporal, social, spatial, and legal dimensions of return and onward migration. Population Space and Place, 17, 131-139.

Jensen, P., \& Pedersen, P. J. (2007). To stay or Not stay? Out-migration of immigrants from Denmark. International Migration, 45(5), 87-113.

Kelly, M. (2013). Onward migration. The transnational trajectories of Iranians leaving Sweden. Uppsala: Department of Social and Economic Geography. Geographica 1.

King, R. (1978). Return migration: a neglected aspect of population geography. Area, 10(3), 175-182.

King, R. (2000). Generalizations from the history of return migration. In B. Ghosh (Ed.), Return migration: journey of hope or despair? (pp. 7-55). Geneva: International Organization for Migration.

King, R. (2002). Towards a new map of European migration. International Journal of Population Geography, 8, 89-106.

King, R., Thomson, M., Fielding, T., \& Warnes, T. (2004). Gender, age and generations. State of the art report, cluster C8, SCMR-Sussex Centre for migration and population studies. Falmer: University of Sussex. Accessed September 2013.

Kofman, E. (2004). Family related migration: a critical review of European Studies. Journal of Ethnic and Migration Studies, 30(2), 243-262

Kraler, A., Kofman, E., Kohli, M., \& Schmoll, C. (2011). Gender, generations and family in the international migration. Amsterdam: Amsterdam University Press.

Mara, I., \& Landesmann, M. (2013). The steadiness of migration plans and expected length of stay: based on a recent survey of Romanian migrants in Italy, Norface Migration Discussion Paper 7.

Massey, D. S., Arago, J., Hugo, G., Kouaouci, A., Pellegrino, A., \& Taylor, J. E. (1993). Theories of international migration: a review and appraisal. Population and Development Review, 19(3), 431-466.

Mazzucato, V., Kakbi, M., \& Smith, L. (2006). Transnational migration and the economy of funerals: changing practices in Ghana. Development and Change, 37(5), 1047-1072.

Nauck, B., \& Settle, B. (2001). Immigrant and ethnic minority families: an introduction. Journal of Comparative Family Studies, 32(4), 461-463.

Nekby, L. (2006). The emigration of immigrants, return vs onward migration: evidence from Sweden. Journal of Population Economics, 19, 197-226.

Newbold, K. B., \& Bell, M. (2001). Return and onwards migration in Canada and Australia: evidence from fixed interval data. International Migration Review, 35(4), 1157-1184.

OECD. (2008). International migration outlook SOPEMI-2008 edition, OECD.

Ortensi, L., \& Barbiano di Belgiojoso, E. (2015). Resist, return or re-emigrate? The growing role of female migration models in assessing migratory intention of immigrants in crisis-hit Italy, 12th IMISCOE Conference 25-27 June 2015.

Paul, A. M. (2011). Stepwise international migration: a multistage migration pattern for the aspiring migrant. American Journal of Sociology, 116(6), 1842-86.

Portes, A., Guarnizo, L. E., \& Landolt, P. (1999). The study of transnationalism: pitfalls and promise of an emergent research field. Ethnic and Racial Studies, 22(2), 217-37.

Reagan, P. B., \& Olsen, R. J. (2000). You can go home again: evidence from longitudinal data. Demography, 37(3), 339-350.

Rimoldi, S. M., \& Barbiano di Belgiojoso, E. (2014). Detecting the poor among foreigners: remarks on a convenient equivalence scale. Rivista Italiana di Economia, Demografia e Statistica, LXVIII(3-4), 7-14.

Rooth, D. O., \& Saarela, J. (2007). Selection in migration and return migration: evidence form micro data. Economics Letter, 94, 90-95.

Schapendonk, J. (2012). Turbulent trajectories: African migrants on their way to the European Union. Societies, $22,27-41$.

Schroll, S. (2009). Emigration of immigrants-a duration analysis. Study paper, 24. Denmark: University Press of Southern.

Stark, O. (1991). The migration of labor. Cambridge: Blackwell.

Stark, O., \& Bloom, D. E. (1985). The new economics of labor migration. American Economic Review, 75, 173-178.

Steiner, V., \& Velling, J. (1994). Re-migration behaviour and expected duration of stay of guest workers in Germany. In G. Steinmann \& R. Ulrich (Eds.), The economic consequences of immigration to Germany. Heidelberg: Physica-Verlag.

Strom, S., Venturini, A., \& Villosio, C. (2013). Wage assimilation: migrants versus natives and foreign migrants versus internal migrants, EUI Working papers 30.

Strozza, S. (2010). International migration in Europe in the first decade of the 21st century. Rivista Italiana di Economia, Demografia e Statistica, 64(3), 7-43.

Takenaka, A. (2007). Secondary migration: who re-migrates and why these migrants matter, migration information source.

Taylor, J. E. (1999). The new economics of labour migration and the role of remittances in the migration process. International Migration, 37(1), 63-88.

Terzera, L. (2015). Scheda 2-Famiglie e progetti di mobilità. In G. C. Blangiardo (Ed.), Limmigrazione straniera in Lombardia. La quattordicesima indagine regionale. Rapporto 2014. 
Toma, S., \& Castagnone, E. (2015). What drives onward mobility within Europe? The case of Senegalese migrations between France, Italy and Spain. Population-E, 70(1), 65-96.

Van Baalen, B., \& Müller, T. (2008). Return intentions of temporary migrants: the case of Germany. Second conference of 'transnationality of migrants' (Marie Curie Research Training Network). Belgium: Université Catholique de Louvain. Louvain-la-Neuve, January 23-24.

Venturini, A., \& Villosio, C. (2008). Labour-market assimilation of foreign workers in Italy. Oxford Review of Economic Policy, 24, 517-541.

Vlase, I. (2013). 'My husband is a patriot!': gender and Romanian family return migration from Italy. Journal of Ethnic and Migration Studies, 39(5), 741-758.

Waldinger, R. (2008). Between 'here' and 'there': immigrant cross-border activities and loyalties. International Migration Review, 42(1), 3-29.

Waldorf, B. (1995). Determinants of international return migration intentions. Professional Geographer, 47(2), 125-136.

Yang, D. (2006). Why do migrants return to poor countries? Evidence from Philippine migrants' responses to exchanges rate shocks. The Review of Economics and Statistics, 88(4), 715-735.

Zaiceva, A., \& Zimmermann, K. F. (2008). Scale, diversity, and determinants of labour migration in Europe. Oxford Review of Economic Policy, 24(3), 427-451.

Zaiceva, A., \& Zimmermann, K. F. (2012). Returning home at times of trouble? Return migration of EU enlargement migrants during the crisis, IZA discussion papers 7111. Bonn: Institute for the Study of Labor (IZA).

Submit your manuscript to a SpringerOpen ${ }^{\circ}$ journal and benefit from:

- Convenient online submission

- Rigorous peer review

- Immediate publication on acceptance

- Open access: articles freely available online

- High visibility within the field

Retaining the copyright to your article

Submit your next manuscript at $\boldsymbol{~ s p r i n g e r o p e n . c o m ~}$ 